\title{
Evaluation of physical and mechanical properties of fired-clay bricks incorporating both mineral and organic wastes
}

\author{
Maryam Achik ${ }^{1}$, Hayat Benmoussa ${ }^{2}$, Abdellah Oulmekki $^{3}$, M. Ijjaali $^{4}$, \\ N. EL Moudden ${ }^{5}$, Olga Kizinievic ${ }^{6}$, Viktor Kizinievic ${ }^{7}$ \\ 1, 2, 3, 4, 5 Faculty of Science and Technology, Sidi Mohamed Ben Abdellah University, Fez, Morocco \\ ${ }^{6,}{ }^{7}$ Institute of Building Materials, Vilnius Gediminas Technical University, \\ Linkmenu g. 28, LT 08217 Vilnius, Lithuania \\ E-mail: ${ }^{1}$ maryam.achik@usmba.ac.ma (corresponding author)
}

\begin{abstract}
The clay brick is one of the oldest building materials, and as the use of waste in the bricks can reduce clay consummation and the environmental burden due to the accumulation of waste, the present study was chosen, the addition of mineral and organic waste to the clay brick.

The added value of this work, which was carried out within the Institute of Building Materials at VGTU, is that the mixture studied is very special, because the raw materials used are:

- Yellow Clay (C) from Fez which is used only in the field of pottery;

- Pyrrhotite Ash (PA) which is a mineral waste produced during the manufacture of sulphuric acid from the roasting of pyrrhotite ore. This waste is stored in the open air since 1982 and until now it doesn't have any specific use;

- Cedar Sawdust (S) is an organic waste regenerate by the artisanal sector from Fez.

The bricks' technological properties depended on the amount of ashes used. So, adding $5 \% \mathrm{~S}$ to the mixture (20\% PA $-80 \% \mathrm{C})$ gives rise to a new material that is light, porous with a natural brick red colour. Most importantly, this material exhibits mechanical strength according to the standards of a terracotta brick.
\end{abstract}

Keywords: clay bricks, pyrrhotite ash, sawdust.

\section{Introduction}

The cost of building materials is often exorbitant, especially when most materials need to be imported. It is preferable to build with locally available materials that may have limited durability, but where the cost is within reach of rural people.

Recently, great attention has been paid to the use of solid waste as secondary raw materials for the production of building bricks. In fact, it is necessary to invent building materials using wastes that spoil the environment to obtain new materials that will serve the environment for a long time.

In this context, and in a previous work that is now being published, the effect of adding pyrrhotite ash to clay bricks was investigated, the results found were satisfactory. It has been found that the addition until $30 \%$ of the pyrrhotite ash to a clay brick treated at $1000{ }^{\circ} \mathrm{C}$ makes it possible to improve several properties, for example the flexural strength varies from 7.66 MPa for $(0 \%)$ to $31.16 \mathrm{MPa}$ for $(30 \%)$. However, the brick becomes heavy and dense. So we opted to add another element that can reduce the weight of the brick while maintaining physic-mechanical properties within the limits.

The present work aims to evaluate the variation of mechanical and physical properties (compressive strength, density, porosity, water absorption, etc.) of fired bricks incorporating an organic waste which is sawdust (waste of artisanal sector of Fez), a mixture of clay and a mineral waste which is the ash of pyrrhotite.

\section{Materials and methods:}

In this study, mixtures of yellow clay from Fez incorporating various percentages of PA and S were used to make a ceramic material. 


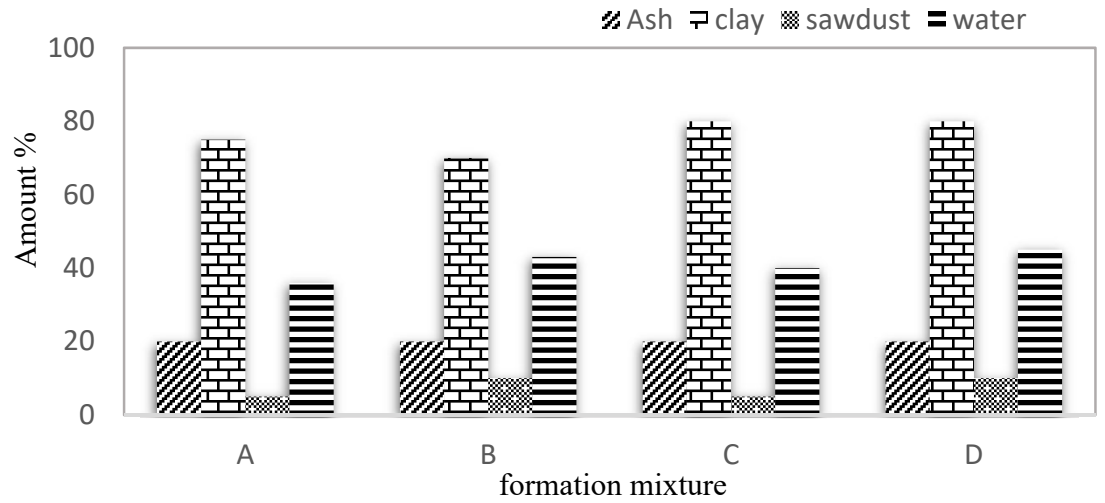

Figure 1. Composition of formation masses ( $\%$ of the mass)

Figure 1 shows the variation of the amount of water with formation mass. It is noted, that the amount of water increases with increasing percentage of sawdust in the formation mass.

The pyrrhotite ash, a result of a former mining operation of the Kettara mine (Zerhouni et al., 2016) is a waste rich in $\mathrm{Fe}_{2} \mathrm{O}_{3}(64.9 \%)$ as well as $\mathrm{SiO}_{2}(13 \%)$ and $\mathrm{Al}_{2} \mathrm{O}_{3}$ (4.01\%) (Achik et al., 2017).

Yellow clay mainly used in the production of ceramic products, it is rich in calcite $\mathrm{CaCO}_{3}$, quartz $\mathrm{SiO}_{2}$, kaolinite $\mathrm{Al}_{2} \mathrm{Si}_{2} \mathrm{O}_{5}(\mathrm{OH})_{4}$, and dolomite $\mathrm{Ca}, \mathrm{Mg}\left(\mathrm{CO}_{3}\right)_{2}$.

Figure 2 shows the stages of clay brick production in general. The gray highlighted boxes indicate the steps we followed. So, the raw material and the additives were dried at a temperature of $100-105^{\circ} \mathrm{C}$ and milled. Initially, the dry mix of the components was mixed, then the mixture was watered until the moisture reached the level suitable for forming. It was noted that it was easy to insert the PA and $\mathrm{S}$ into the formation mass. This formation mass was kept for 24 hours in the desiccator, so that moisture can be evenly distributed in the formation mass. After $24 \mathrm{~h}$ hardening, briquettes of dimensions $1=30 \mathrm{~mm} ; \mathrm{L}=30 \mathrm{~mm}$; $\mathrm{e}=20 \mathrm{~mm}$ were formed from the formation masses.

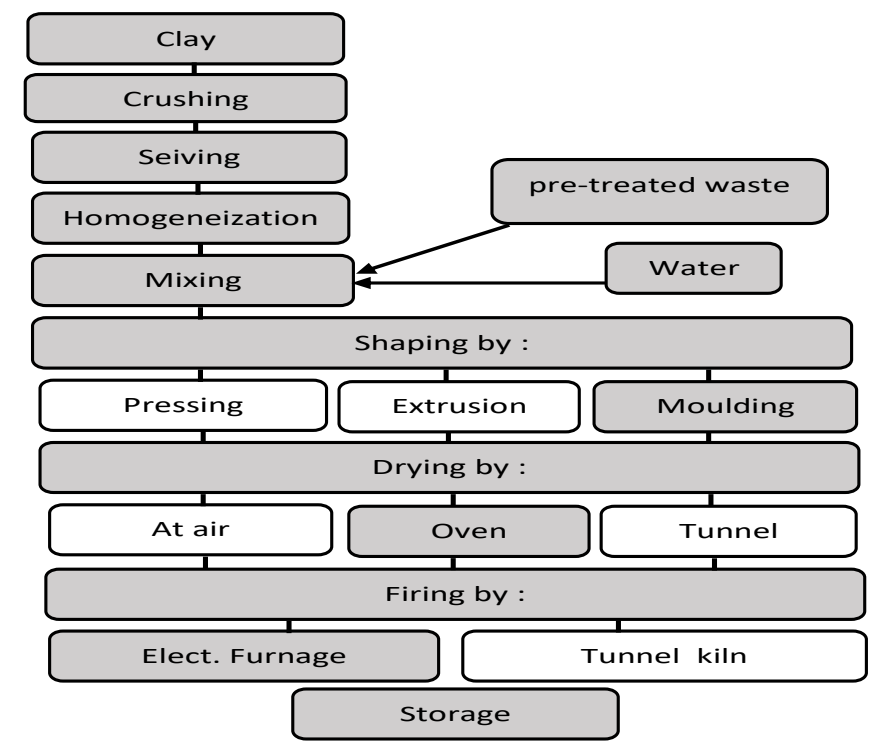

Figure 2. Stages of clay brick production

Initially, the formed semi-products were dried under natural laboratory conditions until stabilization of weight and shrinkage, and then dried in an electric dryer for 24 hours. In this dryer, the samples were dried at a temperature of $105 \pm 5^{\circ} \mathrm{C}$. The combustion of the samples was carried out at both of temperatures $900{ }^{\circ} \mathrm{C}$ and $1000{ }^{\circ} \mathrm{C}$, the burning time was 30 hours, keeping at the combustion 2 hours.

The chemical composition of pyrrhotite ash was already realized at a previous paper (Achik et al., 2017), for chemical composition, physical and mechanical properties of the burned ceramic bodies, it has been determined in the Institute of Building Materials and Laboratory of Composite Materials.

At the Laboratory of Composite Materials the following analysis were performed:

Bricks making according to the simple protocol found in the literature, showed in Figure 2.

The follow-up of the weight loss and the shrinkage of the bricks by the following simple equations: 


$$
\begin{aligned}
\text { Weight loss } & =[(\text { Original Weight }- \text { Fired Weight }) / \text { Original Weight }] * 100 . \\
\text { Shrinkage } & =[(\text { Original Length }- \text { Fired Length }) / \text { Original Length }] * 100 .
\end{aligned}
$$

Total open porosity, Water absorption and density were conducted with the vacuum saturation method (Hall \& Hoff, 2002);

$$
\begin{gathered}
d=\frac{M 0}{M 2-M 1} ; \\
W r=\frac{M 2-M 0}{M 2-M 1},
\end{gathered}
$$

$d$ : density; $W r$ : total porosity (\%); $M 0$ : original mass of the sample (g); $M 1$ : the emerged mass (in water) (g); $M 2$ : the soaked mass (in the air) $(\mathrm{g})$.

And the rest of analysis such as Thermogravimetric analysis ATD/ATG, (DRX) X-ray diffraction, (SEM) scanning electron microscope, and compression strength of bricks, were done in the Institute of Building Materials.

\section{Results and discussions}

Firstly, the shrinkage and weight loss of the bricks were evaluated as a function of the temperature and the percentage of the additives, the results are displayed on the Figures 3 and 4 . The shrinkage is very important in the $105^{\circ} \mathrm{C}$ temperature for the simple reason that the briquettes contain the water of gashing then the shrinkage will be large. Also-at this temperature the shrinkage decreases with the increase of the quantity of sawdust which can be explained by the fact that $105^{\circ} \mathrm{C}$ is not a temperature able to burn the sawdust.

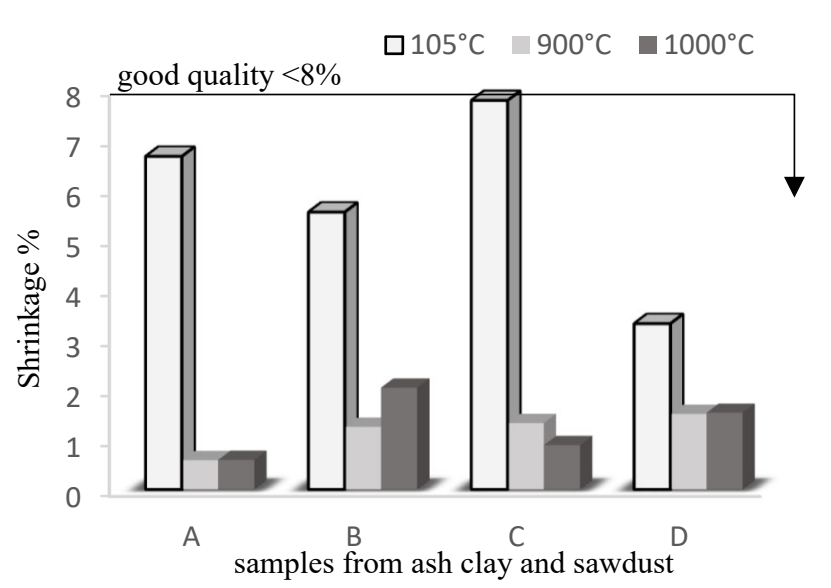

Figure 3. Dependence of the drying and total shrinkage of clay body on the amount of temperature and Sawdust additive

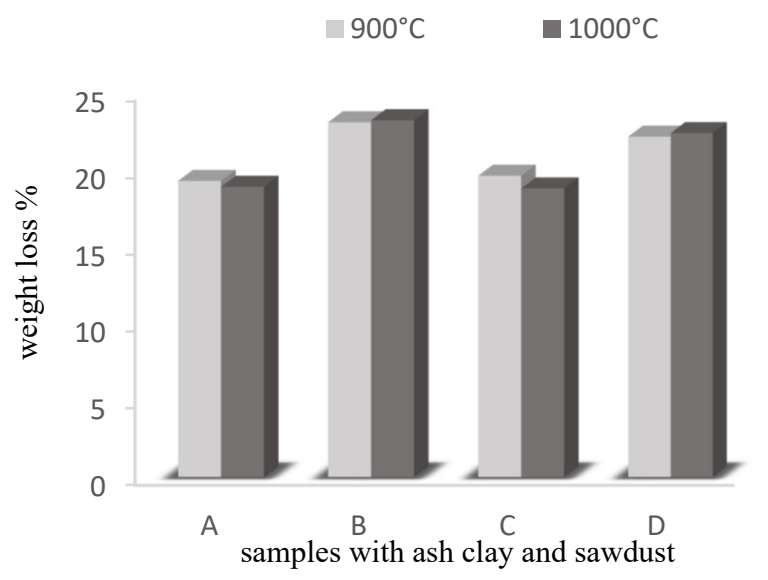

Figure 4. Weight loss of samples as function of temperature and formation mass composition

For the other temperatures it is seen on the Figure 3 that shrinkage increases by increasing the percentage of sawdust but it still under the value of $8 \%$ is the standard required by the literature for shrinkage (Taha, Benzaazoua, Hakkou, \& Mansori, 2016). which is explained by the combustion of the sawdust, because $900{ }^{\circ} \mathrm{C}$ and $1000{ }^{\circ} \mathrm{C}$, are temperatures where it is totally burned, which generates pores leading to the result that absorption of water will be very interesting in these high temperatures.

Water absorption was determined according to NF P 13-305 (Millogo, Hajjaji, \& Ouedraogo, 2008; P. Bachtold, P. Bachtold, \& Rapport, 2018), On the Figures 4 and 5 it is remarkable that the weight loss and the water absorption are parallel depending on the temperature and the sawdust content, for the simple reason is that sawdust burns in high temperatures while leaving pores, then those pores that are responsible for the weight loss and the absorption of water. And according to (Taha et al., 2016; Mezencevova, Yeboah, Burns, Kahn, \& Kurtis, 2012; Eliche-Quesada, FelipeSesé, López-Pérez, \& Infantes-Molina, 2017) the water absorption of clay brick with a good quality should not be superior than $22 \%$ and it is the case for the samples A and C which contain only $5 \%$ of sawdust.

The apparent porosity was tested by the vacuum saturation method according to (Hall \& Hoff, 2002) as following:

Three samples for each percentage are placed in a dissector linked with a pump that is responsible for creating the vacuum as well as evacuate the water, this analysis lasted $140 \mathrm{~min}$. Firstly the samples placed in the dissector for $60 \mathrm{~min}$ under vacuum which was created using a pump under a pressure of $0.9 \mathrm{kgf} / \mathrm{cm}^{2}$, then the dissector filled with water and air and the samples remained in this case for $20 \mathrm{~min}$. Afterward water was injected and creates a vacuum. 
In this case, the samples resists for $20 \mathrm{~min}$, this water-vacuum water-air cycle is repeated twice. Finally the vacuum is removed and the samples are left for 24-hour in desiccator and then weighed in the water and in the air.

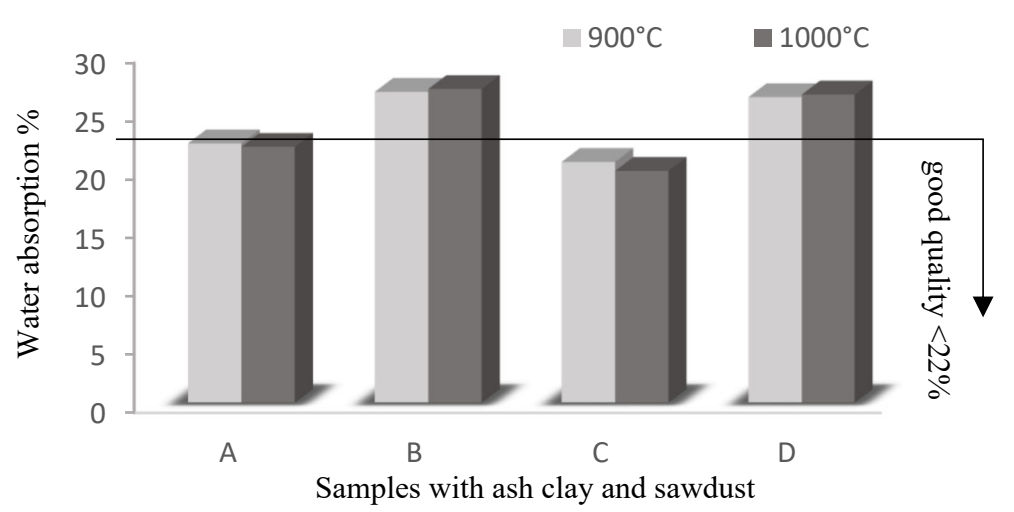

Figure 5. Variation of water absorption with percentage of additives and temperature

The results are displayed on Figure 6 and they are consistent with the previous results of water absorption. The porosity increases with the temperature and the percentage of sawdust. According to the standard (Eliche-Quesada et al., 2017; Taha et al., 2016), the briquettes of good quality must have a porosity between $20 \%$ and $55 \%$. In this case, the porosity values of $\mathrm{A}$ and $\mathrm{C}$ are in this average, while $\mathrm{B}$ and $\mathrm{D}$ have porosity values more than $55 \%$. Indeed, the high amounts of sawdust in B and D should surely affect the density of the samples.

The French standard NF P 94-093 cited by AFNOR 1999 (Bruno, Gallipoli, Perlot-Bascoules, Mendes, \& Salmo, 2015; Camp, Gourc, Plé, Rey, \& Kaelin, 2006), specifies that light bricks of good quality should have densities between [1.5-1.8] g/ $\mathrm{cm}^{3}$ and [1.8-2] g/ $\mathrm{cm}^{3}$ for heavier bricks (Quijorna, Coz, Andres, \& Cheeseman, 2012).

Figure 7 shows that the density decreases by increasing the temperature and the percentage of sawdust, but in spite of this decrease it remains in the standards and included between $1.5 \mathrm{~g} / \mathrm{cm}^{3}$ and $2 \mathrm{~g} / \mathrm{cm}^{3}$ for the four samples.

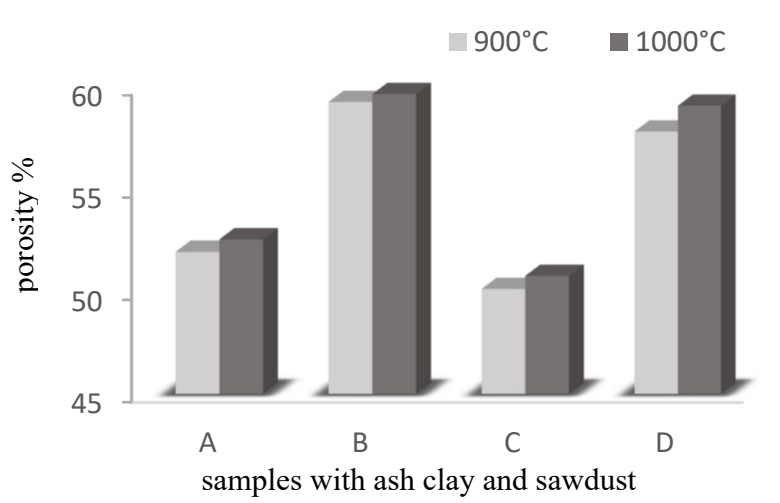

Figure 6. Variation of porosity of the ceramic bodies burned at $1000{ }^{\circ} \mathrm{C}$ and $900{ }^{\circ} \mathrm{C}$ temperature

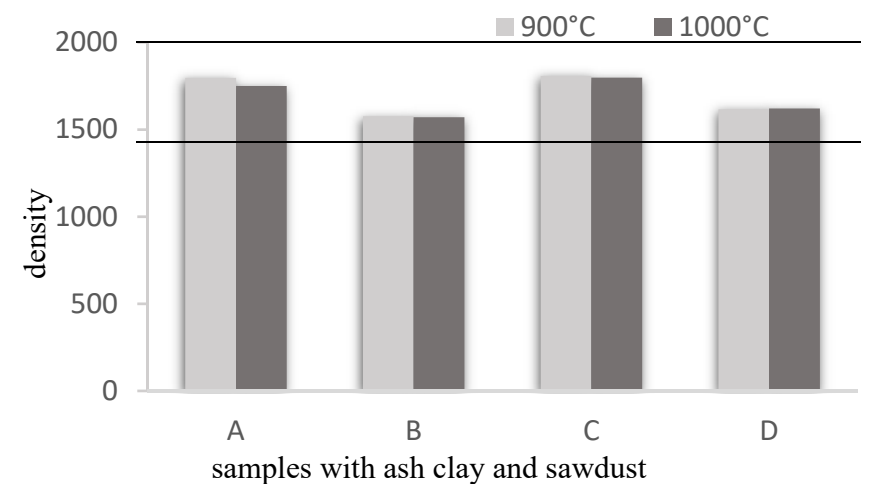

Figure 7. Density of the ceramic bodies burned at $1000{ }^{\circ} \mathrm{C}$ and $900{ }^{\circ} \mathrm{C}$ temperature.

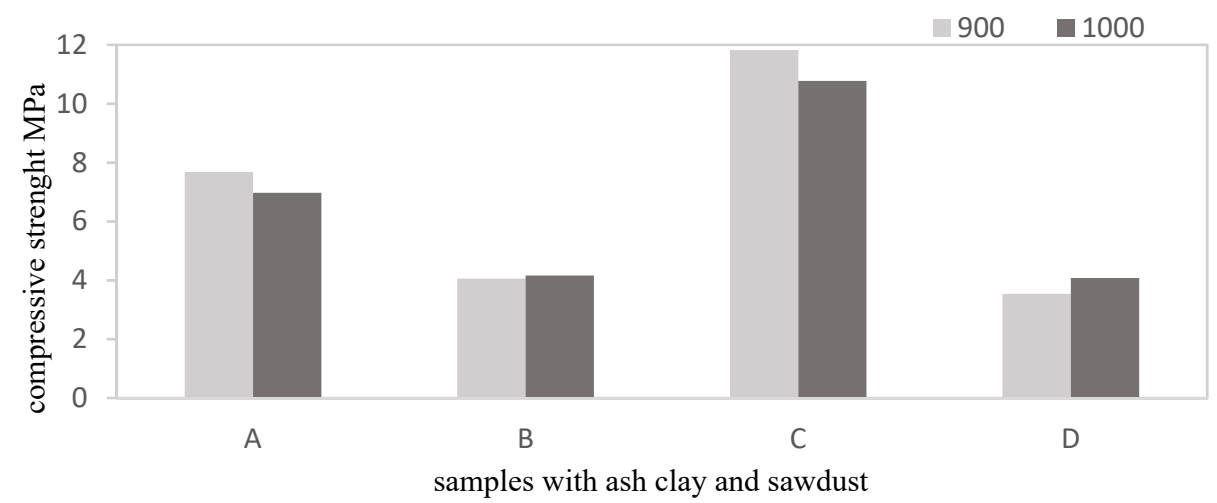

Figure 8. Compressive strength as function of bricks composition and temperature 
According to the standard ASTM C270 (Bruno et al., 2015) the compressive strength for a brick terracotta should have a value between [6.9-27.6] $\mathrm{MPa}$ and it's the case for sample $\mathrm{A}$ and $\mathrm{C}$ in both temperature $900{ }^{\circ} \mathrm{C}$ and $1000{ }^{\circ} \mathrm{C}$. As the sample $\mathrm{C}$ shows the best physical properties compared to the other samples, it appears very well on the Figure 8 that it also has the best mechanical properties with a compression strength of $11.82 \mathrm{MPa}$ at $900{ }^{\circ} \mathrm{C}$ and $10.77 \mathrm{MPa}$ at $1000^{\circ} \mathrm{C}$. Despite the sample $\mathrm{C}$ containing sawdust shows a decrease of the mechanical properties (Turgut, 2008; Turgut \& Murat Algin, 2007), the compression strength is still greater than $7 \mathrm{MPa}$ for this sample.

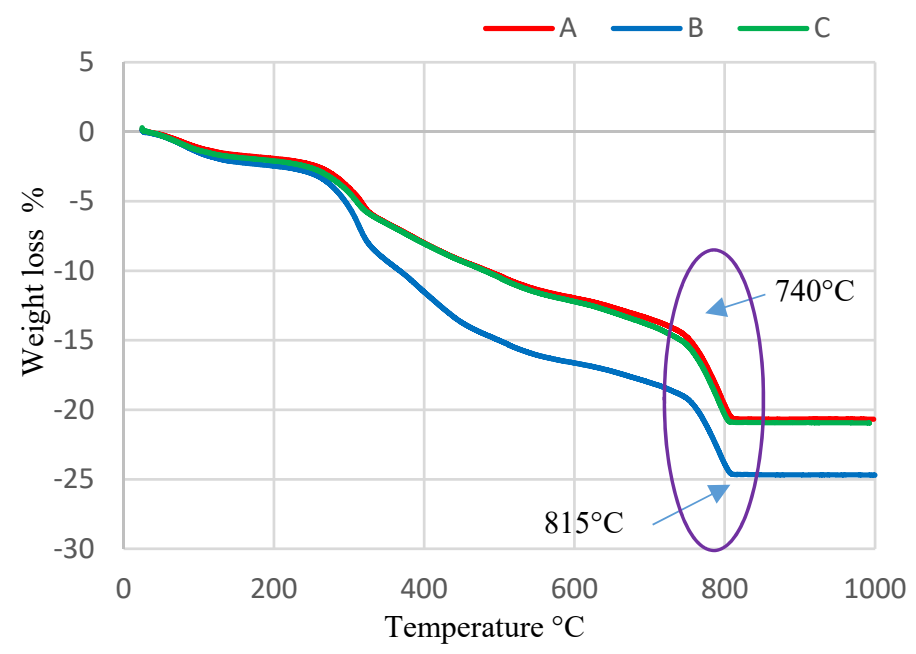

(a)

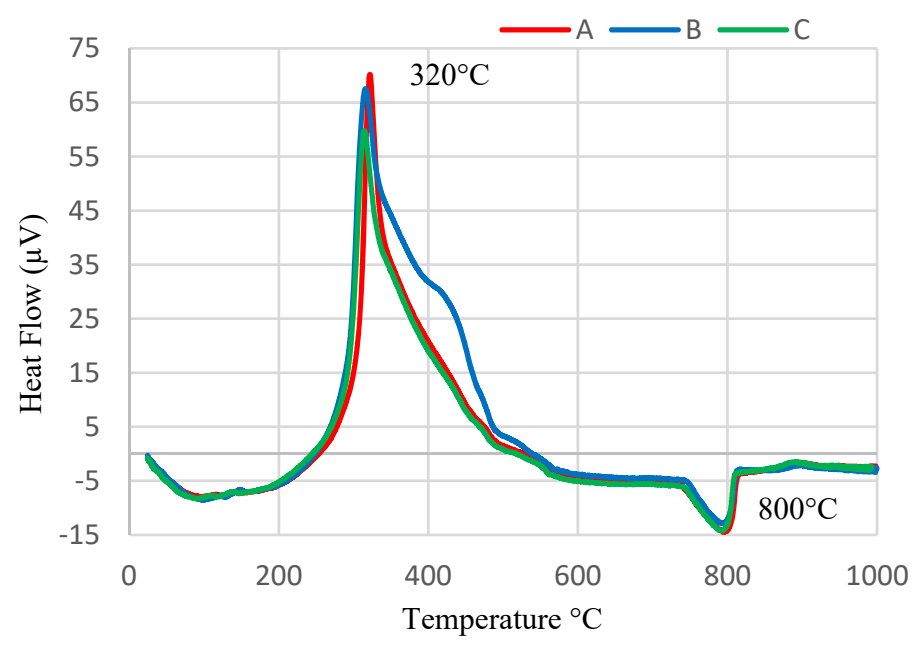

(b)

Figure 9. (a) TG / (b) ATD diagram of clay sawdust and pyrrhotite ash bricks

A general overview of the ATD / TG results shows that all the percentages have the same thermogravimetric results. This indicates that there is no big difference in the composition of these percentages.

The differential thermal analysis of bricks additive (see Figure 9b) shows that the first endothermic effect occurs at $30-250{ }^{\circ} \mathrm{C}$ temperature. Maximal value of this effect was found around $103{ }^{\circ} \mathrm{C}$ temperature and it is related to the extraction of free hygroscopic water from formation mass. Mass losses during this dehydration process reach $1.2 \%$. Further endothermic effect is followed by exothermic effect. It occurs at the temperature from $250-600{ }^{\circ} \mathrm{C}$, the maximum of this effect is observed around $320^{\circ} \mathrm{C}$ temperature for the three percentages. During this effect mass of the sample decreases evenly. It is assumed that this exothermic effect is related to the burning out of the organic materials from sawdust. In addition, the crystallization process occurs. i.e. amorphous phase (ferrihydrite) is transformed into crystal phase - hematite (O. Kizinievič, Žurauskienė, V. Kizinievič, \& Žurauskas, 2013) (Sadūnas.A, 1999) . Loss of mass at $320{ }^{\circ} \mathrm{C}$ temperature is around $6.7 \%$ for the three samples.

Further endothermic effects are observed at $800{ }^{\circ} \mathrm{C}$ temperatures. During these effects fragmentation of carbonates $\left(\mathrm{CaCO}_{3}, \mathrm{MgCO}_{3}\right)$ occurs with dissipated of $\mathrm{CO}_{2}$ (Kizinievič et al., 2013). Loss of mass during fragmentation of carbonates is around $20.7 \%$ for both percentage A and C, but is $24.7 \%$ for B and that can be explain with the big important contains of sawdust in this sample. 
Achik, M.; Benmoussa, H.; Oulmekki, A.; Ijjaali, M.; EL Moudden, N.; Kizinievic, O.; Kizinievic, V. 2019.

Evaluation of physical and mechanical properties of fired-clay bricks incorporating both mineral and organic wastes

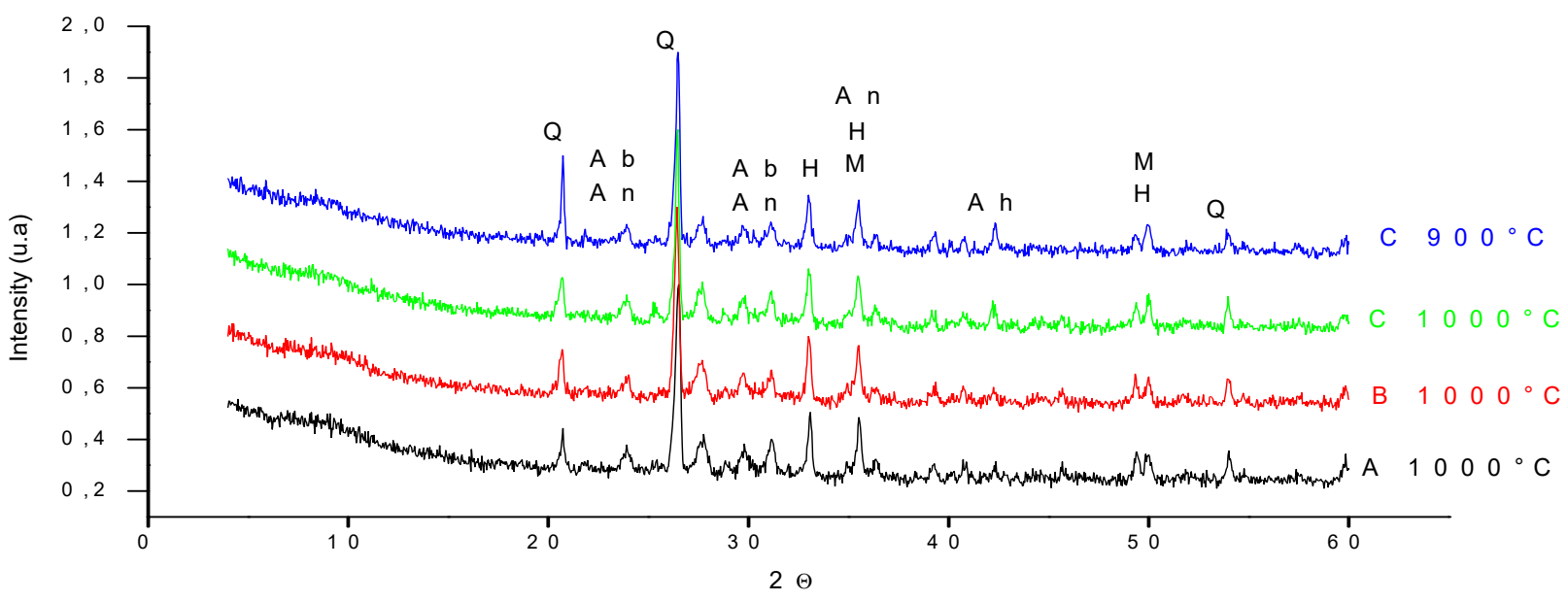

Figure 10. X-ray pattern (nm) of RM: $\left(\mathrm{A}: 1000^{\circ} \mathrm{C}\right),\left(\mathrm{B}: 1000^{\circ} \mathrm{C}\right),\left(\mathrm{C}: 1000^{\circ} \mathrm{C}\right),\left(\mathrm{C}: 900{ }^{\circ} \mathrm{C}\right) ; \mathrm{Q}$ quartz $\mathrm{SiO}_{2}$, An Anorthite $\mathrm{CaAl}_{2} \mathrm{Si}_{2} \mathrm{O}_{8}, \mathrm{Ab}$ Albite $(\mathrm{Ab}) \mathrm{NaAlSi}_{3} \mathrm{O}_{8}, \mathrm{M}$ magnetite $\mathrm{Fe}_{3} \mathrm{O}_{4}, \mathrm{H}$ hematite $\mathrm{Fe}_{2} \mathrm{O}_{3}$

On the Figure 10 the four percentages exhibit the same crystalline phases in both temperature $900{ }^{\circ} \mathrm{C}$ and $1000{ }^{\circ} \mathrm{C}$. It is noticed the presence of quartz, hematite, magnetite, Albite and, Anorthite (Taha et al., 2016).

The only difference is the quartz intensity in the crystalline phase of sample $\mathrm{C}$ at $900{ }^{\circ} \mathrm{C}$, which may explain the mechanical strength of this sample which is the highest.

For SEM analysis the samples are prepared by metallization with gold to increase their conductivity.

For the samples treated at $1000{ }^{\circ} \mathrm{C}$ (Figure 11) the following remarks are noted:

A: presence of carbonate hydroxide and silica

$\mathrm{B}$ : It is noticed that the contact between the clay matrix and the other additives is not good. So, the matrix is more porous because of the percentage of the sawdust which is $10 \%$. Also, $\mathrm{MgO}$ is present in abundance.

$\mathrm{C}$ : a less porous matrix as well as the contact between the components of the matrix is very good.

D: presence of a needle structure corresponding to silica.

A

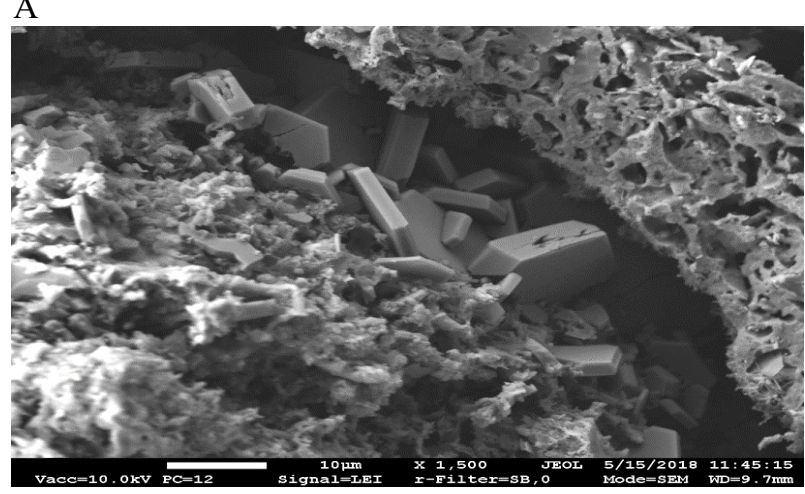

$\mathrm{C}$

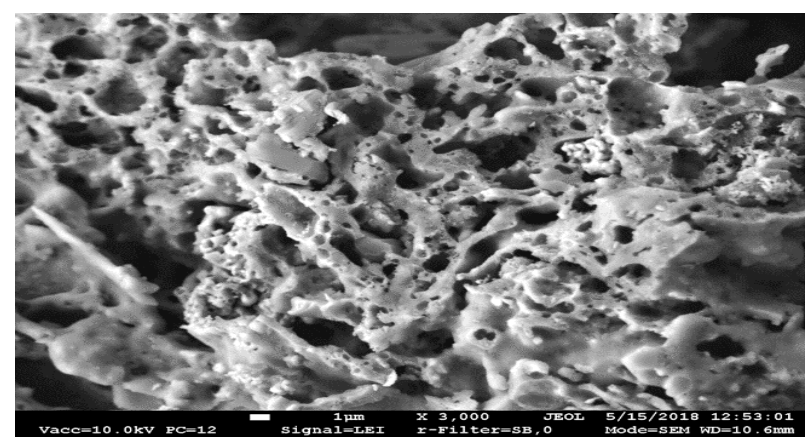

$\mathrm{B}$

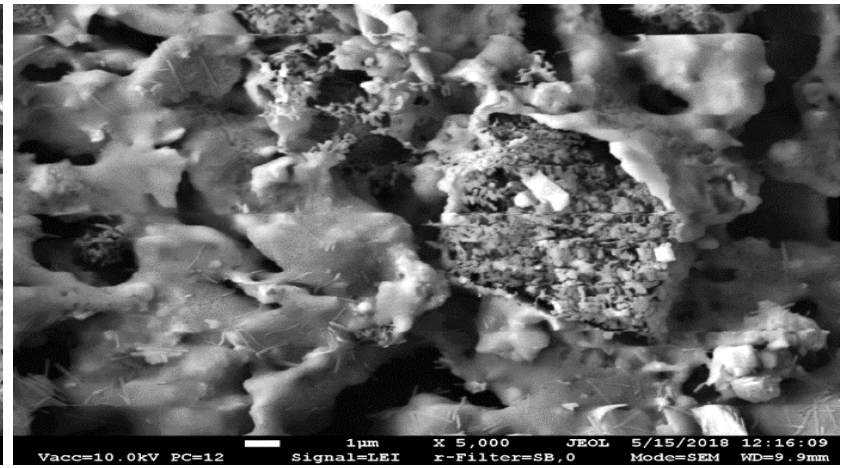

$\mathrm{D}$

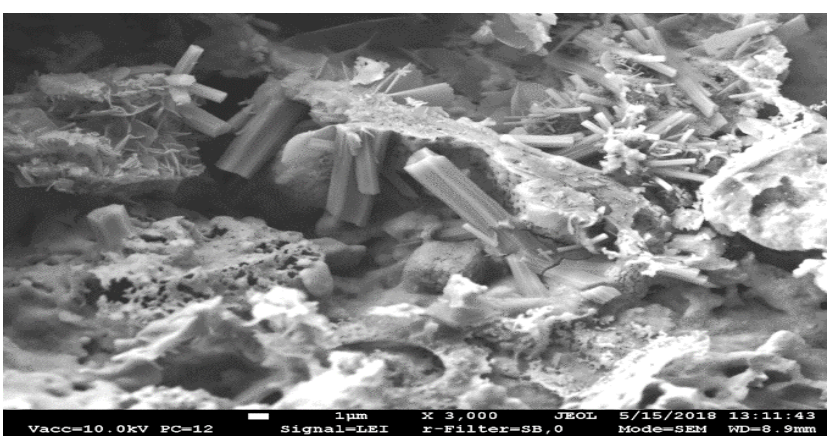

Figure 11. Microstructure evolution of bricks burned at $1000{ }^{\circ} \mathrm{C}$ as a function of sawdust percentage 
For the percentages treated at $900{ }^{\circ} \mathrm{C}$ (Figure 12) it is noted that the interior of the bricks is lighter than the outer surface which can be explained by the presence of sawdust, inside there is calcium oxide but on the surface external there is iron oxide.

A: on the outside the pores have no specific format, they are neither large nor small which is normal for a ceramic body cooked. But inside the pores are too small we also note that the $\mathrm{MgO}$ and $\mathrm{Ca}$ as well as the needle structure are more abundant than in the A treated at $1000{ }^{\circ} \mathrm{C}$;

$\mathrm{B}$ : presence of the needle structures corresponding to sawdust, there is also a petal-shaped structure and $\mathrm{MgO}$. The presence of white dots corresponding to anhydrous $\mathrm{CaS}$ is also noticed;

$\mathrm{C}$ : nothing special either the presence of $\mathrm{CaO}$ crystals and decreasing of pores;

D: the existence of needles and geometric shapes.

A

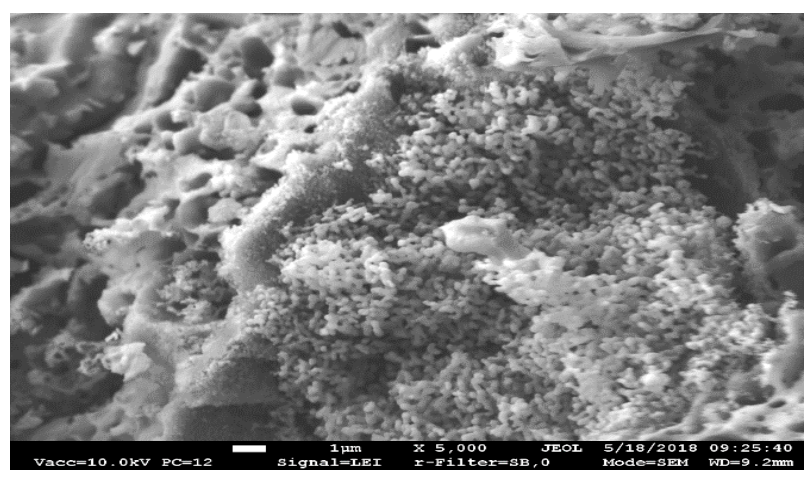

$\mathrm{C}$

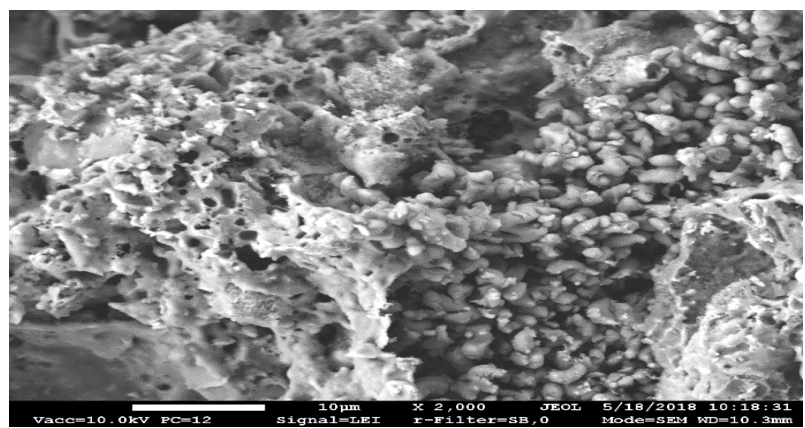

B

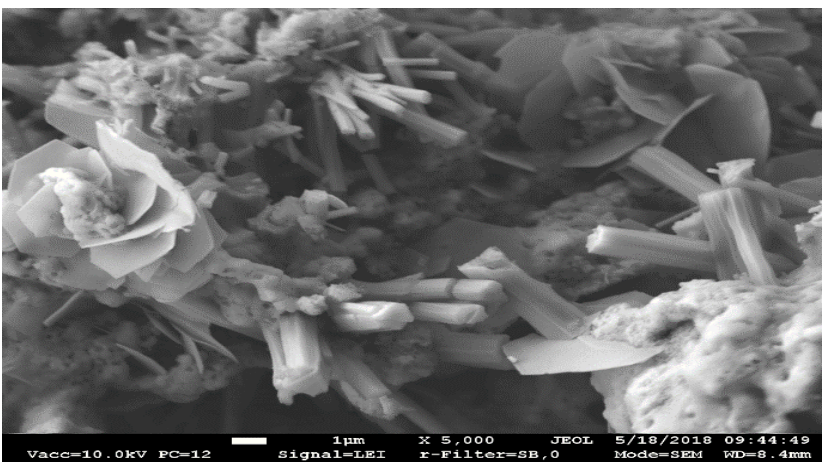

$\mathrm{D}$

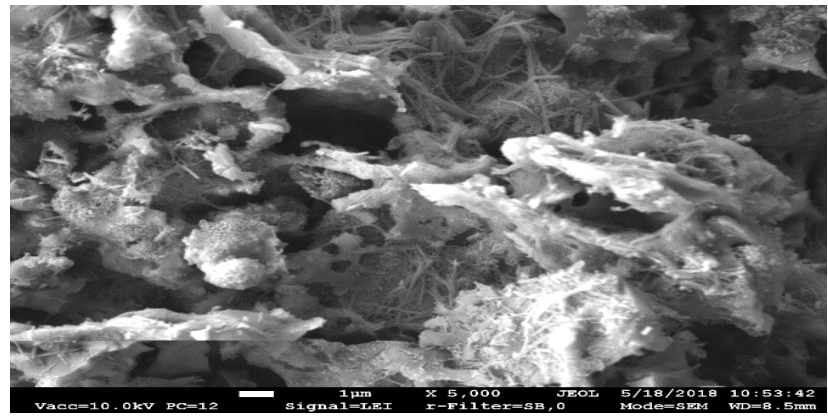

Figure 12. Microstructure evolution of bricks burned at $900{ }^{\circ} \mathrm{C}$ as a function of sawdust percentage

\section{Conclusions}

An experimental study has been carried out on the physic-mechanical properties of terracotta bricks. In order to regulate the physical and mechanical limits of a good brick with the mineral and organic additives added to the yellow clay of Fez, this study was also done to limit the mechanical resistance while decreasing the weight of these briquettes.

Experience shows that the sawdust content of up to $5 \%$ of the total mixture of $20 \%$ pyrrhotite ash and $80 \%$ clay is sufficient to maintain a compressive strength which follows the European standards of a clay briquette.

The effect of adding sawdust is the decrease of their weight, so the brick becomes light. Who says lightweight brick automatically says porous brick and this is the case of the studied samples. Bricks become more porous but meet European standards $(20-55 \%)$ as well as the compression strength is still greater than $7 \mathrm{MPa}$. The evaluation of the coefficients of thermal conductivity and thermal diffusivity is expected and-will begin in a later work.

Finally, the main objective of this study is achieved in a satisfactory way. Two wastes could be valorised in building bricks. The first is mineral (PA) and the second is organic (S). Moreover, the clay used in this study was until now only used in the field of pottery. So, a new material for building bricks that meets European standards was obtained. 
Achik, M.; Benmoussa, H.; Oulmekki, A.; Ijjaali, M.; EL Moudden, N.; Kizinievic, O.; Kizinievic, V. 2019.

Evaluation of physical and mechanical properties of fired-clay bricks incorporating both mineral and organic wastes

\section{References}

Achik, M., Oulmekki, A., Ijjaali, M., Benmoussa, H., EL Moudden, N., EL Khattabi, S., EL Khattabi, R., Ahjyyaj, F.-Z., Gonzalez Alvaro, G., \& Guitian Rivera, F. (2017). Physicochemical characterization of an industrial waste: A case study of the pyrrhotite ash from south west of Morocco. Journal of Materials and Environmental Science, 8(8), 2738-2746. http://www.jmaterenvironsci.com/Document/vol8/vol8_N8/313-JMES-Achik.pdf

Bachtold, P., Bachtold, P., \& Rapport, D. (2018). Pour l'élaboration d'un manuel de construction. https://hal.archives-ouvertes.fr/hal-01894376

Bruno, A. W., Gallipoli, D., Perlot-Bascoules, C., Mendes, J., \& Salmon, N. (2015). Briques de terre crue: procédure de compactage haute pression et influence sur les propriétés mécaniques. https://hal.archives-ouvertes.fr/hal-01167676/

Camp, S., Gourc, J.-P., Plé, O., Rey, D., \& Kaelin, J.-L. (2006). Comportement mécanique de l' argile de couverture d' un centre de stockage de déchets très faiblement radioactifs (pp. 1-8). http://oldgc.iut-nimes.fr/internet/augc/Papiers/003_cam.pdf

Eliche-Quesada, D., Felipe-Sesé, M. A., López-Pérez, J. A., \& Infantes-Molina, A. (2017). Characterization and evaluation of rice husk ash and wood ash in sustainable clay matrix bricks. Ceramics International, 43(1, Part A), 463-475. https://doi.org/10.1016/j.ceramint.2016.09.181

Hall, C., \& Hoff, W. D. (2002). Water transport in brick, stone and concreate ( $1^{\text {st }}$ ed.). CRC Press, London. https://doi.org/10.4324/9780203301708

Kizinievič, O., Žurauskienè, R., Kizinievič, V., \& Žurauskas, R. (20013) Utilisation of sludge waste from water treatment for ceramic products. Construction and Building Materials, 41, 464-473. https://doi.org/10.1016/j.conbuildmat.2012.12.041

Mezencevova, A., Yeboah, N. N., Burns, S. E., Kahn, L. F., \& Kurtis, K. E. (2012). Utilization of Savannah Harbor river sediment as the primary raw material in production of fired brick. Journal of Environmental Management, 113, 128-136. https://doi.org/10.1016/j.jenvman.2012.08.030

Millogo, Y., Hajjaji, M., \& Ouedraogo, R. (2008). Microstructure and physical properties of lime-clayey adobe bricks. Construction and Building Materials, 22(12), 2386-2392. https://doi.org/10.1016/j.conbuildmat.2007.09.002

Quijorna, N., Coz, A., Andres, A., \& Cheeseman, C. (2012). Recycling of Waelz slag and waste foundry sand in red clay bricks. Resources, Conservation and Recycling, 65, 1-10. https://doi.org/10.1016/j.resconrec.2012.05.004

Sadūnas, A. (1999). Aliumosilikatu degimas redukuojančiu-oksiduojančiu dujų terpejje [Burning of aluminium silicates in the medium of reducing and oxygenating gases]. Vilnius: VPU 1-kla. $187 \mathrm{p}$.

Taha, Y., Benzaazoua, M., Hakkou, R., \& Mansori, M. (2016). Natural clay substitution by calamine processing wastes to manufacture fired bricks. Journal of Cleaner Production, 135, 847-858. https://doi.org/10.1016/j.jclepro.2016.06.200

Turgut, P. (2008). Properties of masonry blocks produced with waste limestone sawdust and glass powder. Construction and Building Materials, 22(7), 1422-1427. https://doi.org/10.1016/j.conbuildmat.2007.04.008

Turgut, P., \& Murat Algin, H. (2007). Limestone dust and wood sawdust as brick material. Building and Environment. Pergamon, 42(9), 3399-3403. https://doi.org/10.1016/j.buildenv.2006.08.012

Zerhouni, Y., Nfissi, S., Alikouss, S., Saber, N., Zahour, G., Baroudi, Z., \& Samir, M. (2016). Caractérisation Des Boues De Sucrerie Et Des Argiles Pour La Neutralisation Des Résidus Miniers Acides De La Mine De Kettara (Jebilet Centrales, Maroc). European Scientific Journal, ESJ, 12(15), 321.https://doi.org/10.19044/esj.2016.v12n15p321 